\title{
SOMEBODY TO BLAME: ON THE CONSTRUCTION OF THE OTHER IN THE CONTEXT OF THE COVID-19 OUTBREAK
}

\author{
SEBASTIÁN MORENO BARRENECHE ${ }^{1}$ \\ ${ }^{1}$ Universidad ORT Uruguay, Department of Political Science, Faculty of Management and Social Sci- \\ ences, Bulevar España 2633, 11300 Montevideo, Uruguay. ORCID: 0000-0003-3551-7117, Email: \\ morenobarreneche@gmail.com
}

\begin{abstract}
Besides the impact that COVID-19 has had in the sanitary, political and economic domains, it has also triggered multiple discursive processes, what opens up the field for an analysis from sociosemiotics, the social science interested in the study of 'meaning in action'. The aim of this article is to discuss from such a perspective how the current crisis linked to the COVID-19 virus has given place to the emergence of processes of narrative construction of an 'Other' to be blamed for the threat. While in some contexts the dominant narrative has been that COVID-19 is 'the Chinese' -and their unhealthy culinary habits-fault, in others the focus has been set on 'the irresponsible' that do not stay home when indicated to do so, as well as on 'the posh', given that they can afford travelling and hence can import the virus on their return. Departing from the premise which poses that cognition is articulated in narrative terms, the article argues how, in cases such as the current COVID-19 crisis, a discursive construction of collective actors by means of mechanisms of actorialization, generalization and axiologization is necessary for the dynamics of blame-attribution. KEYWORDS: coronavirus, COVID-19, sociosemiotics, constructivism, blame
\end{abstract}




\section{SOMEBODY TO BLAME. ON THE CONSTRUCTION OF THE OTHER IN THE CONTEXT OF THE COVID-19 OUTBREAK}

In January 2020, a virus until that moment unknown by the scientific community gained attention world-wide due to the speed of its propagation: the 'novel coronavirus', popularly known simply as 'coronavirus', who when infecting humans causes the disease that has been named 'COVID-19'. Its diffusion started in the Chinese province of Huabei -its main focus being the city of Wuhan- and it quickly spread to the whole world. For observers and analysts based in Europe, the coronavirus became more real when the first cases of infection were diagnosed in Italy, in February 2020. Its reach became so broad, that on 11 March 2020 the World Health Organization declared it a pandemic, and nowadays it is considered a major threat for global health. According to WHO official data, by 30 March 2020, world-wide there are more than 600,000 confirmed cases, over 30,000 deaths and more than 200 countries, areas or territories with confirmed cases of infection.

There are few things as representative of the natural realm as a virus. If one accepts the contested analytical distinction between 'nature' and 'culture' (Descola 2005; Koschorke 2009), a virus such as the novel coronavirus clearly belongs to the domain of the former. Nevertheless, despite its biological nature, it also impacts strongly the socio-cultural dimension: when perceived -and interpreted-as a threat, it generates individual and collective feelings such as fear and panic, gives place to the implementation of political measures that has frozen the economy of several countries, and leads to controversial decisions that limit civil rights such as freedom of movement and of association. All these are socio-cultural effects that have been caused by the perception, interpretation, and 'reading' that humans make of the virus, which as a result becomes a threat. Departing from this general premise, the overarching goal of this article is to discuss the dynamics of this sort of effects of the coronavirus and the resulting disease -COVID-19- on the socio-cultural dimension. As these are many and of diverse nature, the focus will be set on a specific issue: the discursive dimension associated to the dynamics of collective blame-attribution in the context of the COVID-19 pandemic.

Assuming that a virus is spread -even if it is involuntarily- by individual actors by becoming part of a chain of contagion, the case of COVID-19 has shown in a clear manner how in a context of a situation of collective fear, specific discourses emerge regarding blame-attribution. These discourses open the field regarding what blaming someone means. In this context, as it proves difficult to identify individual actors to put the blame on ('Who brought the virus to country X?', 'Who infected individual Y?'), collective actors have been constructed in order to make blame-attribution possible. Due to the semiotic mechanisms involved in this process, specific tags have been linked to these sort of 'imagined communities' (Anderson 1983), which have been used as escape goats to relief the feeling of impotence linked to the fear caused by the abnormal situation linked to the outbreak. At the beginning, when the spread of the novel coronavirus was still regarded by the WHO as an epidemic, the collective actor 'the Chinese' was blamed for the origin of the virus due to their gastronomic 
customs, which were usually judged as unhealthy and primitive. When in February 2020 the virus became highly visible in Italy, in some European countries a narrative emerged blaming 'the Italians' for the spread of the virus, pointing out to their allegedly reckless manners and 'Southern' lifestyle. In some Latin American countries such as Uruguay and Argentina, where the first infected cases date from mid-March 2020, the collective identity 'the posh' ('los chetos', in the local degrading slang terminology) has been identified as the social actor to be blamed, as they are the ones who can afford travelling to places where the virus is spread and, as a result, import the virus into their own countries on their return. Last but not least, nowadays there is an ever-growing discourse that stigmatizes the collective actor of 'the irresponsible' that do not stay home, its most visible case being the spring-breakers in the United States (Bella 2020; The Guardian 2020a).

To sum up, within the context of the COVID-19 outbreak, several Others have been constructed in discourse in order to articulate a -narrative- explanation for the spread of the virus. As it normally happens in every narrative emplotment, it seems to be the case that there needs to be a sort of villain, i.e., an actor with agency -and hence with the capability of making moral choices- to be blamed for the circumstances. If perception is mediated by the principle of narrativity - understood not as "a particular type of discourse, but as a deep structure that can be found in every discourse" (Paolucci 2012:299)-, then it is understandable that facts are integrated into narrative articulations -stories, social discourses, imaginaries-in which specific actors fulfill specific thematic roles. This article examines from a sociosemiotic perspective such mechanisms of discursive construction of the Other as a central instance in the dynamics of blame-attribution in the context of the COVID-19 outbreak. In what follows, the first section introduces the research field of sociosemiotics, the second discusses fear as an emotion that is socially constructed, the third examines identity from a constructivist perspective as the result of the establishment of differences following an imagined distinction between the collective actors of 'we' and 'they', and the fourth and final focuses on the mechanisms of collective identity construction and blame-attribution in the context of the COVID-19 outbreak.

\section{SOCIOSEMIOTICS: THE STUDY OF 'MEANING IN ACTION’}

Semiotics was first conceived as a discipline by Swiss linguist Ferdinand de Saussure, who in his Cours de linguistique générale, published in 1916, presented it as the sill inexistent science whose interest would be set on studying the life of signs in the framework of social life, and hence a sub-discipline of social psychology. Departing from this general idea, during the $20^{\text {th }}$ century semiotics grew as an autonomous research field, even if it never managed to break completely its link with linguistics and philosophy of language: authors such as Roland Barthes, Charles Sanders Peirce, Algirdas Greimas and Umberto Eco, who nowadays are regarded as ‘fully-fledged' semioticians, started their intellectual careers by studying language. This link gave place to a conceptualization that persisted for years of semiotics as the science that studies signs and sign systems (Hénault 2012; Landowski 2019), leading to its categorization 
by many as "abstract and removed from the way the world actually works" (Lorusso 2015:2).

In spite of this original focus on signs and sign systems, during the last decades there has been a methodological turn within the discipline: researchers have shifted their focus of interest from specific manifestations of language in the form of standard verbal and audiovisual texts to a broader spectrum of phenomena, such as practices, interactions, trajectories, and situations, amongst many others, by using the analytical category of 'text' as a model of analysis (Landowski 2014; Marrone 2011). Researchers such as Jean-Marie Floch (1990), Jacques Fontanille (2008), Eric Landowski (2014), Patrizia Violi (2014), and Gianfranco Marrone (2001), to mention only a few of well-known names within the discipline, started applying the concepts, theories and methods of traditional semiotic theory to the study of 'meaning in action', i.e., the signifying processes that take place within -and that at the same time, construct and reproduce- the social realm (Hénault 2012; Landowski 2014; Landowski 2019; Lorusso 2015). As Floch (1990:22) argues in a book that nowadays is a reference of applied semiotics, the discipline can be defined by considering its field of research: "languages - all languages- and signifying practices, which essentially are social practices", making its scholarly aim "the description of the conditions of production and understanding of meaning”. This is why, according to Landowski (2014:10), semiotics "claims to account for the way how sense emerges from daily life and lived experience with its many dimensions”, while Eliseo Verón (1988:125), based on the assumption that "every social phenomenon is, in one of its constitutive dimensions, a process of meaning-making", indentifies the scope of the discipline with "the reconstruction of the production of meaning within the inter-discursive networks of our societies" (Verón 1989:138). Similarly, Anna Maria Lorusso (2015:2) identifies "the processes and practices within which meaning, in its multiplicity of languages, exists" as the object of study of semiotics.

Independently of the signifier chosen to refer to this research field -'sociosemiotics', 'semiotics of culture', etc.-, what matters is the agreement regarding the object of study. Due to the expansion of its scope, this research field became significantly close to other social sciences such as anthropology (Lorusso 2010; Landowski 2016). Within anthropology, the work of Clifford Geertz (1973) presents significant commonalities with the sociosemiotic approach. Geertz (1973:4) is broadly known for his semiotic account according to which "culture consists of socially established structures of meaning in terms of which people do [...] things as signal”. More generally, he writes:

Believing [...] that man is an animal suspended in webs of significance he himself has spun, I take culture to be those webs, and the analysis of it to be therefore not an experimental science in search of law but an interpretative one in search of meaning. (Geertz 1973:5)

For Geertz (1973:11), culture can be read and interpreted as a text, given that cultural practices -such as cockfights in Bali, which he famously studied-, and human behavior in general, are seen as "symbolic action -action which, like phonation in speech, pigment in painting, line in writing, or sonance in music, signifies”. Hence, 
Geertz supports an interpretative approach to culture based on conceiving it as a complex text that needs to be decoded by employing the method of 'thick description', aimed at "gaining access to the conceptual world in which our subjects live so that we can, in some extended sense of the term, converse with them" (1973:23). This approach seems to be in line, just to mention an example, with what Susan Sontag tried to do in her book Illness as Metaphor (1978), where she examined the metaphors associated to diseases such as tuberculosis and cancer with the aim of demystifying them. In other words, the aim of cultural analysis can be conceived as "sorting out the structures of signification [...] and determining their social ground and import" (Geertz 1973:10). Similarly, in A Theory of Semiotics Umberto Eco (1976) made the effort of formulating a general theory of semiotics that could study any signifying phenomenon based on sign-functions. According to Eco (1976:22), "humanity and society exist only when communicative and significative relationships are established", what leads him to formulate a methodological premise according to which "the whole of culture should be studied as a communicative phenomenon based on signification systems". This premise is also underlying the work of Verón (1988:125), who believed that "every form of social organization, every system of action, every set of social relations, implies, in its own definition, a signifying dimension”. That is why, according to Verón (1988:126), "meaning is interlinked in an inextricable manner with social behaviour", and meaning-making is to be considered as the basis for "the material organization of society, its institutions and its social relations".

To sum up, the focus of scholars researching the socio-cultural dimension from a semiotic perspective is set on how meaning emerges, circulates, and is consumed within the webs of inter-subjectivity that constitute 'culture', which is characterized by permanent and complex processes of semiosis, that is, of emergence of signifying functions. As Verón argues (1988:126), "it is in semiosis that the reality of the social is constructed", while Lorusso (2015:3) conceives semiosis as "a social institution". It is because of this focus that, as Lorusso (2015:2) argues, "semiotics can 'match' with other scientific paradigms", based on the fact that it shares with them "assumptions, practices, and authors of reference".

\section{FEAR AS A SOCIAL CONSTRUCTION}

Underlying the sociosemiotic outlook is a constructivist premise according to which social reality is constructed by means of specific processes of interpretation and meaning-attribution. As a theoretical account, constructivism has gained strength during the last decades in several social sciences and the humanities, affecting discussions within sociology (Berger and Luckmann 1966), social psychology (Gergen 1999), international relations (Wendt 1992) and philosophy (Searle 1995). In spite of the many existing constructivist accounts, the basic premise of constructivism is the denial of realism and of other essentialist accounts that consider reality as something given and pre-social; for constructivists, reality itself is a social construction based on intersubjective agreement in which language helps to construct, maintain and reproduce that reality. 
In line with this general tenet, during the last couple of decades several semioticians studied social and collective phenomena such as memory, trauma and conflict from a semiotic perspective, paying attention at how specific cognitive and emotional processes take place in the form of dynamics of semiosis. In this general context, emotions such as fear and panic are understood as social constructions based on intersubjective processes of meaning-making, both on the individual and the collective level. Regarding the individual level, Hutchinson and Bleiker (2014:505) argue that "what people feel physiologically as emotions is the product of social and cultural encounters and of how individuals have been socialized into managing their emotions through and within such encounters". That is why, even if it is true that the emotions an individual feels have a bodily anchorage, these are not innate or natural: emotions should be conceived as 'cultural products', because "feelings are formed and structured within particular social and cultural environments" (Hutchinson and Bleiker 2014:504). As the authors argue, "to experience feelings such as anger, fear, trust, or empathy is dependent on a specific cultural context that renders such emotions meaningful and acceptable".

The same principle applies for the collective dimension of fear and panic. Members of a society feel these emotions in their bodies when there is a dominant discourse that constructs a threat in narrative terms. In the achievement of such a perception, there are semiotic mechanisms involved: on the one hand, the cognitive, which is related to a specific perception of reality and facts based on an articulated set of normative and evaluative parameters (e.g. 'COVID-19 is a threat for my/our well-being'); and on the other hand, the affective, which is triggered by the cognitive process and refers to the actual emotions that the interpretation of facts produces on the individuals. In the transition from the former to the latter, semiosis plays a central role, given that it is the "signifying dimension of social phenomena" (Verón 1988:125) and, as such, articulates perception and emotions in a narrative manner, departing from the dominant semiotic premise according to which "narrativity is the form of meaning that structures thought" (Paolucci 2012:303).

Taking this framework to the case of the COVID-19 outbreak, the virus itself would not be considered a major global threat without a discursive environment that transforms every confirmed infection or death in an actualization of that mainstream narrative: infections and deaths trigger specific interpretative processes, both at the individual and collective level, that support the confirmation of the interpretative hypothesis 'COVID-19 is a threat'. Such a discursive environment is fostered inter-subjectively, for example by interpersonal conversations, official declarations of government and experts, viral content and memes shared on social media, and media coverage. In this environment, an objective fact ('a new virus is infecting a high number of people in a very short period of time') becomes a threat because specific meanings are attributed to it based on a broader narrative that serves as the interpretative framework. Fear and panic are, hence, the product of social discourse and, as Verón (1988:126) argues, “a sociosemiotics can only be a theory of the production of social discourses".

When analyzing phenomena such as the COVID-19 outbreak from a sociosemiotic perspective, it is essential to keep in mind that fear is socially constructed, and 
therefore the object of research should be social discourse, with a specific focus on its narrative dimension, i.e., who are the actors involved in the narrative, which is their relationship, what is the 'object of value' that is being disputed, and which is the logic of the interactions between the actors in order to gain access to that object. Within this conceptualization, based on the principle that assumes that narrativity is "the semiotic form capable of rendering thought meaningful" (Paolucci 2012:304), threats take a narrative form, including the construction of an actor that is responsible of that threat (Cosenza 2018). As Helger Mölder (2011:34) argues, a "culture of fear increases the role of instability and anxiety in social discourses and relationships and makes distinctions between friendly Us and hostile Others”. As a result, a specific type of discourse is permanently constructed by means of textual and narrative articulations, where collective actors such as 'We, humanity' and 'It, the virus' are not only constructed, but also axiologized positively and negatively, as we shall see in the next section.

\section{IDENTITY AND THE 'WE'/'THEY' DICHOTOMY}

Identities, both individual and collective, do not escape the logic of meaning-making based on a narrative articulation discussed above: they are inter-subjective co-constructions based on a negotiation of meaning articulated around the principle of recognition. This means that an identity only exists if there is an interpreter who recognizes it as such. As a result, from a constructivist perspective identities cannot be defined in an essentialist manner, i.e., based on fix, stable and given sets of properties; instead, they are defined from a relational perspective, which identifies them as meaningful units by means of the establishment of differences with other identities. That is why Leonor Arfuch (2005) believes that identities are 'relational positions'. Such a theoretical premise can be found, for example, in the sociolinguistic research of Bucholtz and Hall (2005:585-586), who argue that identities are "a relational and socio-cultural phenomenon that emerges and circulates in local discourse contexts of interaction rather than as a stable structure located primarily in the individual psyche or in fixed social categories". Identities, both individual and collective, are constructed by means of cognitive processes linked to articulations of meaning based on a narrative principle.

When dealing with collective identities, the discursive construction of the multiple meaningful units and categories that are part of the narrative -for example, in the case of national identity, 'the Polish', 'the Uruguayans', and so on- takes place by establishing an imaginary dichotomy between a 'We' and a 'They'. Both actors result from a semiotic mechanism in which reality is segmented arbitrarily in groups that are imagined not only as different, but homogeneous and monolithic as well. This phenomenon has been studied in detail, amongst others, in the political realm (Mouffe 2005; Cosenza 2018) and in the context of nationalism studies (Anderson 1983). The premise is that, if there is a 'We', imagined as unitary and homogeneous, it is because there has been a discursive construction of an Other, relationally defined as 'non-We', which is also imagined as unitary and homogeneous. As Fornäs (2012:43) argues when 
studying the idea of a 'European' identity, "identities are formed by signification processes spun around specific individuals or groups, where people in thought and action link somebody or something to a range of meanings representing characteristic traits and values for that person or collective". This process of meaning-making implies a number of cognitive mechanisms whose core is semiotic, that is, related to semiosis, such as actorialization, generalization and axiologization.

Actorialization can be defined as the construction of collective actors on the discursive dimension. This implies the definition of a collective identity based on the establishment of arbitrary boundaries that separate 'units of meaning'. As Eco (1976:73) showed in $A$ Theory of Semiotics based on the research of linguist Louis Hjelmlev, meaning is to be conceived not referentially, but as 'cultural unit' that is "placed in a system of other cultural units which are opposed to it and circumscribe it"; therefore, Eco argues (1976:66), "every attempt to establish what the referent of a sign is forces us to define the referent in terms of an abstract entity which moreover is only a cultural convention". Every narrative configuration implies some actors, which are discursively constructed. In the case of the COVID-19 outbreak, a number of actors have been constructed in discourse. On the side of the heroes, 'the workers of the health system', an imagined actor whose members are unknown from an individual perspective and whose bravery is in several countries recognized on a daily basis with a collective round of applause. But on the other side, as it was mentioned in the Introduction, a number of Others have been constructed: 'the Chinese', 'the Italians', 'the posh', and 'the irresponsible', amongst others. Even if they might have an anchorage on factual events, these 'cultural units of meaning' that have been arbitrarily delimited, fulfill a cognitive function: if the unit of meaning 'the Chinese' occupies a role in the mainstream narrative articulated around the COVID-19 outbreak, then specific attributes and connotations will be attributed following a deductive logic to individual actors that are recognized as members of that group, leading to xenophobic and racists judgments. Besides the arbitrary segmentation, there is a process of generalization, in which the specific individual units that are imagined as part of the collective actor are assumed to be the same or, at least, share their core properties. Collective actors, then, in their quality of being discursive constructions based on the attribution of a homogeneous identity to an imagined group, gain life as opposed to other actors, also imagined, based on the dichotomy anchored on the pronouns 'We' and 'They'.

When dealing with collective identities, however, the most interesting semiotic mechanism involved in the social construction of the Other is axiologization, which consists in the attribution of specific value and normative connotations to the collective actors that have been created in discourse. Following Anne Hénault (2012:275), axiologization can be defined as "the static valorization of a given universe of discourse", what implies a normative and value-loaded dimension that adds positive and/ or negative marks to the units of meaning that have been arbitrarily delimited, including the collective identities that are of our interest. Chantal Mouffe (2005:5) identified that the 'We'/'They' dichotomy that structures the field of political discourse, axiologization takes place on a moral register: as she argues, "the we/they, instead of being defined with political categories, is now established in moral terms" following 
a narrative of a struggle between 'right' and 'wrong', what produces a transformation in the conception of the political opponent from an adversary to an enemy. It is in this way that, in the field of politics, the Other gains specific negative marks and connotations, which sometimes represent a major obstacle for dialogue and rational political struggle.

\section{ACTORIALIZATION AND BLAME-ATTRIBUTION IN THE CONTEXT OF THE COVID-19 OUTBREAKE}

This section will focus on two major issues: on the one hand, the discursive construction of the multiple Others in the case of the COVID-19 outbreak; and on the other, the role these discursive constructions might play in a narrative scheme of blame-attribution.

Regarding the former, based on the theoretical framework discussed in the previous pages, some specific collective actors have been not only constructed based on the mechanisms of actorialization and generalization, but they have also been strongly axiologized and regularly used as 'escape goats' to explain the threat that the virus poses in narrative terms. As Argentinean journalist Verónica Abdala (2020) discusses in a very recent piece, the fact that the virus was originated in the Chinese city of Wuhan has produced a surge of xenophobic and racist attitudes, in the form of "a rejection in the whole world towards restaurants and shops managed by Chinese citizens, besides discriminatory and racist episodes towards individuals with Asian features”. This phenomenon is also reported by Laurie Chen (2020a; 2020b), who in a coverage of the awareness-raising action staged in Florence by Massimiliano Martigli Jiang -an Italian-Chinese individual- writes that "as in other Western countries, there has been a surge in xenophobic incidents targeting Chinese people in Italy in the wake of the deadly coronavirus outbreak”. For Suyin Haynes (2020), this wave of discrimination "is not only targeting mainland Chinese people, but people of east and south east Asian descent more broadly, including those who are not first-generation immigrants". Moreover, in a recent piece, Becky Little (2020) identifies in the United States a historical record characterized by a "biased way of associating immigrants with disease”.

The use of the unit of meaning 'the Chinese' - an imagined collective actor that is constructed discursively and hence arbitrarily- in the narrative that attributes blame for the spread of the COVID-19 has been fueled by allegations done by political actors on China's -the state, represented by its governmentresponsibility in the outbreak, like for example Donald Trump's reference to the virus as the 'Chinese virus', a denomination that has been strongly criticized, especially after a photograph of his speaking points in which the original phrase 'corona virus' was manually replaced by 'Chinese virus' circulated online. Moreover, there are reports that indicate that political actors close to Trump used the expression 'Kung Flu' to refer to the virus (Orbey 2020; Rogers, Jakes, and Swanson 2020), and it has been reported that Republican Senator John Cornyn declared that "China is to blame, because the culture where people eat bats and 
snakes and dogs and things like that [...]" (Orbey 2020), a statement that takes the discursive construction to a cultural level, beyond the political dimension. As Eren Orbey (2020) argues, "the terror of Trump's finger-pointing is not only that it will surely exacerbate the misdirected anger and violence against Asians and Asian-Americans; it's that his jingoism undermines the collective effort that's essential to slowing the virus's spread".

In short, in reference to the case of China as a state, China as a cultural unit and 'the Chinese', it can be clearly seen how the three units of meaning tend to merge into one, given that the signifier 'China', besides referring to a country -an administrative unit with clear boundaries, sovereignty and a government that can be held accountable for its actions-, also refers to another clusters of meaning, linked to the collective identity of 'the Chinese', whose boundaries and defining properties are not so well-established as in the case of the political unit: to blame 'the Chinese' for the spread of the virus represents an oversimplification that is handy when trying to emplot and explain facts in narrative terms, but that is not accurate. Nevertheless, for many it is still a key piece in the narrative explanation of the current extraordinary circumstances. In opposition, some counter-narratives also have emerged, such as the one condensed in the \#JeNeSuisPasUnVirus hashtag that has been promoted in France by the French-Asian community as a form of denouncing discrimination (Chen 2020a).

A second case of interest can be found in the situation that took place in countries such as Argentina and Uruguay, where the virus was imported to these countries by travelers arriving from Europe. As Abdala (2020) points out, in Argentina the spread of COVID-19 was initially associated to a specific social class, what also happened in Uruguay, where one of the first confirmed cases of infected individuals - on 13 March 2020 - was a fashion designer who in early March arrived to the country from Spain and, instead of putting herself in a preventive self-quarantine, the night of her arrival attended a massive wedding (The Guardian 2020). Her identity, as well as humoristic -and at the same time stigmatizing- viral content quickly spread on social media, including some voice messages from individuals clearly recognizable due to their tone and language as being part of the imagined collective actor of 'the posh'. This fueled very quickly the hypothesis that the COVID-19 had been introduced in Uruguay by 'the posh', a collective identity that in Uruguayan social discourse is linked to Carrasco, a residential neighborhood in the capital city Montevideo. In a context of strong political polarization articulated in the form of class-belonging attributed to a hegemonic political discourse associated to left-wing political actors, this single occurrence became an actualization of the interpretative narrative that blames 'the posh'.

Having discussed some of the examples of how collective actors are imagined and constructed in discourse by means of specific semiotic mechanisms, a brief discussion of the process of blame-attribution will follow, with the aim of understanding why collective actors as the ones discussed above need to be created -and axiologized-in order to consolidate the narrative on the spread of the COVID-19. This will be done based on philosopher Thomas Scanlon's $(2008$; 2013) account, who conceives blame as "a class of responses to morally faulty actions" that implies "a modification of one's understanding of one's relationship with the person blamed", particularly of the ex- 
pectations towards them (Scanlon 2013:84-86). The concept of relationship plays a central role in Scanlon's account, as blaming someone implies modifying the relationship one has with them. For Scanlon (2013:84), a relationship is "a set of intentions and expectations about our actions and attitudes toward one another that are justified by certain facts about us". This account can be easily applied to the case of interpersonal relations such as friendship and family, but what happens in cases such as the one that is of interest in this article, in which actors are not individuals, but collective identities?

To cover these impersonal situations - that is, situations in which one cannot know the person that is to be blamed for an action-, Scanlon introduces the idea of the 'moral relationship', which according to the author is universal, inescapable and holds among all rational agents. As Scanlon (2013:87) argues, "the moral relationship does not apply only to people who know of or are acquainted with one another or who actually have certain attitudes towards one another": it is a normative relationship that we all stand in with all the other individuals, which establishes that "we should have certain general intentions about how we will behave toward other rational creatures" (2013:87), even if we do not know them. It is based on the idea of this moral relationship that Scanlon builds his account of blame: "blame and blameworthiness [...] are always relative to some relationship or relationships" (2013:88), what makes holding a relationship a precondition for blame-attribution to take place: if there is no relationship, there simply cannot be blame-attribution. It is here where the principle of narrativity that articulates cognition can be of help.

From a semiotic perspective, it could be argued that in impersonal cases, i.e., in cases in which one cannot identify a specific individual or social actor to blame, the process of blame-attribution based on the moral relationship gives place to a process of imagination and discursive construction in narrative terms of the agent to be blamed. For blame-attribution to take place, such construction is a necessary condition. In the case of interpersonal relations, one can always attribute responsibility to someone's actions that are prejudicial to one in a narrative manner, such as, for example, in the case in which a friend or relative that does not want to self-confine him/herself and that, as a result of that action, infect us with the virus. But in the case of impersonal relations -which are the dominant case in the context of the COVID-19 outbreak, given that asymptomatic contagion is possible-, the actor to be blamed needs to be discursively constructed, so that the blame can be put on them following the articulating narrative principle in which an agent acts morally wrong and therefore can be blamed. In other words: in a context in which it is difficult to find individual escape goats to blame for infecting others, it is simpler to construct discursive actors and held them responsible for the catastrophe. In this sense, the discursive construction of the Other seems to be a clear confirmation of the cognitive hypothesis regarding the central role of narrativity in the articulation of perception: to make sense of the abnormal circumstances, someone needs to be blamed, because narrativity implies causality and agency. 


\section{CONCLUDING REMARKS}

This article should serve not only as a proof to show the actuality of sociosemiotic thinking nowadays, but also as a way of bringing into attention the relevance that social discourses and the principle of narrativity play in how individuals and other social actors perceive reality. In times of confusion, fear and even social chaos, identifying the social discourses that structure the debate will certainly help to deal with uncertainty in a more accurate way. Moreover, the reflections presented in the previous pages should be put in perspective with regards to a challenging paradox that is anchored in the nature of the virus, who does not recognize the identities, arbitrarily established, that structure human perception such as nationality or social class.

FUNDING: This research received no external funding.

CONFLICT OF INTEREST: The author declares no conflict of interest.

\section{REFERENCES}

Abdala, Verónica. 2020. "El chino, el cheto, el irresponsable: cuáles son los prejuicios en torno al coronavirus." Clarín. Retrieved from https://www.clarin.com/cultura/chino-cheto-irresponsable-prejuicios-torno-coronavirus 0 fUEc1rHi-. html?fbclid=IwAR2wNEwUvZrVOdYOZbhSmtFlLqloifbHFYCKaZCfZVqe3C9CTsV5N8y1zDM

Anderson, Benedict. 1983. Imagined Communities. London: Verso.

Arfuch, Leonor, ed. 2005. Identidades, sujetos, subjetividades. Buenos Aires: Prometeo.

Bella, Timothy. 2020. “'If I get corona, I get corona': Miami spring breakers say covid-19 hasn't stopped them from partying.” The Washington Post. Retrieved from https:// www.washingtonpost.com/nation/2020/03/19/coronavirus-spring-break-party/

Berger, Peter and Thomas Luckmann. 1966. The Social Construction of Reality. London: Penguin.

Bucholtz, Mary and Kira Hall. 2005. "Identity and Interaction: A Sociocultural Approach.” Discourse Studies 7(4-5): 585-614.

Chen, Laurie. 2020a. "I am not a virus, I am a human being: Italian-Chinese man's video spreads anti-racist message on social media." South China Morning Post. Retrieved from https://www.scmp.com/news/china/society/article/3050499/iam-not-virus-i-am-human-being-italian-chinese-mans-video

-----. 20202b. "Coronavirus: outbreak has stoked a rise in xenophobia, Chinese living abroad say.” South China Morning Post. Retrieved from https://www.scmp.com/ news/china/society/article/3049423/coronavirus-outbreak-has-stoked-rise-xenophobia-chinese-living

Cosenza, Giovanna. 2018. Semiotica e comunicazione politica. Bari/Rome: Laterza.

Descola, Philippe. 2005. Par-delà nature et culture. Paris: Gallimard.

Eco, Umberto. 1976. A Theory of Semiotics. Bloomington: Indiana University Press. 
Floch, Jean-Marie. 1990. Sémiotique, marketing et communication. Paris: Presses Universitaires de France.

Fontanille, Jacques. 2008. Pratiques sémiotiques. Paris: Presses Universitaires de France. Fornäs, Johan. 2012. Signifying Europe. London: Intellect Books.

Geertz, Clifford. 1973. The Interpretation of Cultures. New York: Basic Books.

Gergen, Kenneth. 1999. An Invitation to Social Construction. London: Sage.

Haynes, Suyin. 2020. “As Coronavirus Spreads, So Does Xenophobia and Racism.” Time.

Retrieved from https://time.com/5797836/coronavirus-racism-stereotypes-attacks/

Hénault, Anne. 2012. Les enjeux de la sémiotique. Paris: Presses Universitaires de France. Hutchinson, Emma and Bleiker, Roland. 2014. "Theorizing Emotions in World Politics.” International Theory 6(3): 491-514.

Koschorke, Albrecht. 2009. „Zur Epistemologie der Natur/Kultur-Grenze und zu ihren disziplinären Folgen." Deutsche Vierteljahrsschrift für Literaturwissenschaft und Geistesgeschicte 83(1): 9-25.

Landowski, Eric. 2014. "Sociossemiótica: uma teoria geral do sentido.“ Galáxia 27: 1020.

-----. 2016. “A prueba del otro.” Contratexto 26: 13-29.

-----. 2019. “Politiques de la sémiotique.” Rivista Italiana di Filosofia del Linguaggio 13(2): 6-25.

Little, Becky. 2020. “Trump’s ‘Chinese’ Virus Is Part of a Long History of Blaming Other Countries for Disease.” Time. Retrieved from https://time.com/5807376/virus-name-foreign-history/

Lorusso, Anna Maria. 2015. Cultural Semiotics. London: Palgrave/Macmillan.

Marrone, Gianfranco. 2001. Corpi sociali. Torino: Einaudi.

-----. 2011. Introduzione alla semiotica del testo. Bari/Rome: Laterza.

Mölder, Helger. 2011. "The Culture of Fear in International Politics - A Western-Dominated International System and Its Extremist Challenges." in Current Debates in International Relations, edited by E. B. Shiraev and V. M. Zhubok. Oxford: Oxford University Press.

Mouffe, Chantal. 2005. On the Political. London: Routledge.

Orbey, Eren. 2020. “Trump's 'Chinese Virus' and What's at Stake in the Coronavirus's Name.” New Yorker. Retrieved from https://www.newyorker.com/culture/cultural-comment/whats-at-stake-in-a-viruss-name

Paolucci, Claudio. 2012. "Sens et cognition: La narrativité entre sémiotique et sciences cognitive.” Signata 3: 299-316.

Rogers, Katie, Lara Jakes, and Ana Swanson. 2020. “Trump Defends Using 'Chinese Virus' Label, Ignoring Growing Criticism.” The New York Times. Retrieved from https://www.nytimes.com/2020/03/18/us/politics/china-virus.html

Scanlon, Thomas. 2008. Moral Dimensions: Permissibility, Meaning, Blame. Cambridge: Harvard University Press.

-----. 2013. “Interpreting Blame.” in On Blame, edited by N. Tognazzini \& D. J. Coates. Oxford: Oxford University Press.

Searle, John. 1995. The Construction of Social Reality. London: Penguin. 
Sontag, Susan. 1978. Illness as Metaphor. New York: Farrar, Straus and Giroux.

The Guardian. 2020a. “If I get corona, I get corona': the Americans who wish they'd taken Covid-19 seriously.” The Guardian. Retrieved from https://www.theguardian.com/lifeandstyle/2020/mar/28/americans-who-dont-take-coronavirus-seriously

------. 2020b. "Half of Uruguay's coronavirus cases traced to a single guest at a society party.” Retrieved from https://www.theguardian.com/world/2020/mar/19/uruguay-coronavirus-party-guest-argentina

Verón, Eliseo. 1988. La semiosis social. Barcelona: Gedisa.

-----. 1989. “Semiótica y teoría de la democracia.” Revista de Occidente 92: 130-142.

Violi, Patrizia. 2014. Paesaggi della memoria. Milano: Bompiani.

Wendt, Alexander. 1992. "Anarchy is what Stakes Make of it: The Social Construction of Power Politics.” International Organization 46(2): 391-425.

\section{BIOGRAPHICAL NOTE}

Sebastián Moreno Barreneche holds a Degree in Philosophy (University of the Republic, Uruguay) and a Degree in Communications (Catholic University, Uruguay). He has a MA in Global Studies (University of Graz, Austria) and a MA in Political, Legal and Economic Philosophy (University of Berne, Switzerland). He also attended postgraduate courses in the fields of Political Science (University of Munich, Germany) and Semiotics (University of Bologna, Italy). He currently is Associate Lecturer at the Faculty of Management and Social Sciences of the Universidad ORT Uruguay, where he lectures on 'Contemporary culture and society' in the Degree in International Studies. His academic interests and research are focused on discursive and cultural practices in various contexts, like the socio-political sphere, issues related to cultural and national identity, and digital environments.

OPEN ACCESS: This article is distributed under the terms of the Creative Commons Attribution Non-commercial License (CC BY-NC 4.0) which permits any non-commercial use, and reproduction in any medium, provided the original author(s) and source are credited.

ARTICLE HISTORY: Received 2020-03-30 / Accepted 2020-04-06 